\title{
Under the stars of Matariki...
}

\section{Keri-Anne Wikitera}

\author{
Dr Keri-Anne Wikitera is a \\ lecturer/researcher working \\ in the School of Hospitality \\ and Tourism at AUT \\ University. Her Māori tribal \\ affiliations are Tūhourangi \\ Ngāti Wahiao and Ngāti \\ Whakaue of Te Arawa.
}

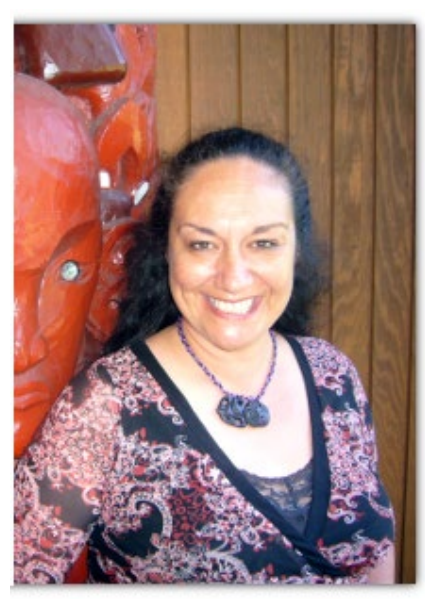

Tēnā koutou katoa, ngā mihi nui mo te tau hou

Greetings and happy new year.

Matariki, the Māori New Year, is a season when people, culture, language and the spirit of those beneath the stars of Matariki are celebrated. Also known as the constellation of Pleiades, Matariki is a star cluster that first appears in the night sky above Aotearoa during mid-winter. It is a time to remember those who have passed throughout the year and reflect on ancestral knowledge to guide us into how we can live our lives today.

When Matariki will appear is knowledge that comes from the maramataka - a calendar informed by the moon, the stars and our natural environment. Within it, navigation, planting, fishing and many other practices are determined by thousands of years of observation, recording and practice. According to the maramataka, Matariki brings the old lunar year to a close and marks the beginning of the new year [1]. Guided by such ancient knowledge systems, Māori hospitality for me is about connection, it is understanding, it is aroha, it is life. Life that embraces not just the person but also the natural world, for we descend from our sacred mountains, seas and ancestors.

With the recent announcement by the New Zealand Government of Matariki becoming a public holiday from 2022, the whole nation prepares for annual Indigenous celebrations [2]. This highlights the importance the nation places on Indigenous knowledge and is demonstrating, in a very real way, how Aotearoa New Zealand can engage with mātauranga Māori (Māori knowledge systems). For the hospitality and tourism industry, once the borders are reopened, the Matariki celebrations will further enhance how Aotearoa New Zealand can showcase our uniqueness, our innovative spirit and recognise the lessons of our ancestors in providing important insights for the future.

At this time of the year, the nation is engaging in these Indigenous celebrations, boosting local economies as communities come together to have fun with a multitude of events. Dawn blessings welcoming the stars of Matariki, lightshows, manu aute (kite) days, special planting rituals, remembrance events, wānanga (educational) forums, workplace 'New Year' festivities, school events and many other gatherings that respectfully acknowledge the physical, cultural and spiritual significance of the maramataka, the Māori calendar. There are variations in how Matariki is celebrated throughout the country. Social media abounds with advertisements and promotions for many 
different Matariki experiences, which are engaging whole communities in te ao Māori (the Māori world).

Perhaps due to the 2020 pandemic lockdowns or the impending 2022 public holiday, there is a real buzz to events this year. This season, more than any other it seems, Matariki is bringing together communities, imbuing the philosophy of manaakitanga, where hospitality extends beyond commercial transactions and focusses on reciprocity of kindness and care [e.g., 3]. A Māori cultural representation of hospitality that continuously seeks to uplift the mana (prestige, spiritual power) of individuals or groups of people. Regional Councils partnering with mana whenua (tribal customary authority of an identified area), a government Matariki advisory group, government agencies, educational facilities and private organisations are all getting involved in promoting relationships that reflect the essence of Māori culture.

How does this all relate to Hospitality Insights? Well, the past year has been extremely challenging for the industry around the world and continues to impact us here in Aotearoa via border closures affecting demand by keeping out international students, tourists and expatriate visits as well as supply, where workers from outside Aotearoa, essential staff for hospitality businesses, are not able to gain entry to the country.

Business sustainability has taken on a new meaning as the tourism and hospitality industries are now dealing with the uncertainty of travel bubbles, the potential for further lockdowns, and the inability to attract international staff. At a national level, having an extra public holiday in the winter will help the hospitality and tourism sectors as domestic markets plan more mid-winter travel.

The pandemic has also been a time to reflect on systemic challenges caused by the industry's acceleration in recent years. Overtourism turned into undertourism overnight, and with this dramatic unforeseen change came an opportunity to pause, to reflect and, in the words of Tourism NZ, 're-imagine' a new future for the nation. Under the stars of Matariki, within the philosophy of manaakitanga, we as a nation now have the opportunity to embrace change, to care for each other and to create a sustainable future that recognises the interwoven universe. A more sustainable, Māori-informed future for tourism and hospitality destinations, communities and tourists alike.

\section{Corresponding author}

Keri-Anne Wikitera can be contacted at: keri-anne.wikitera@aut.ac.nz

\section{References}

(1) Te Papa Tongarewa Museum of New Zealand. What is Matariki?, 2021. http://tpo.tepapa.govt.nz/ViewTopicExhibitDetail.asp?TextSize=Medium\&Language= English\&TopicFileID=TTY T8 (accessed Aug 9, 2021).

(2) NZ Government. 2022 Matariki Holiday Date Announced, 2021. https://www.beehive.govt.nz/release/2022-matariki-holiday-date-announced (accessed Aug 9, 2021).

(3) Spiller, C.; Erakovic, L.; Henare, M.; Pio, E. Relational Well-Being and Wealth: Māori Businesses and an Ethic of Care. Journal of Business Ethics 2011, 98 (1), 153-169. https://doi.org/10.1007/s10551-010-0540-z 
